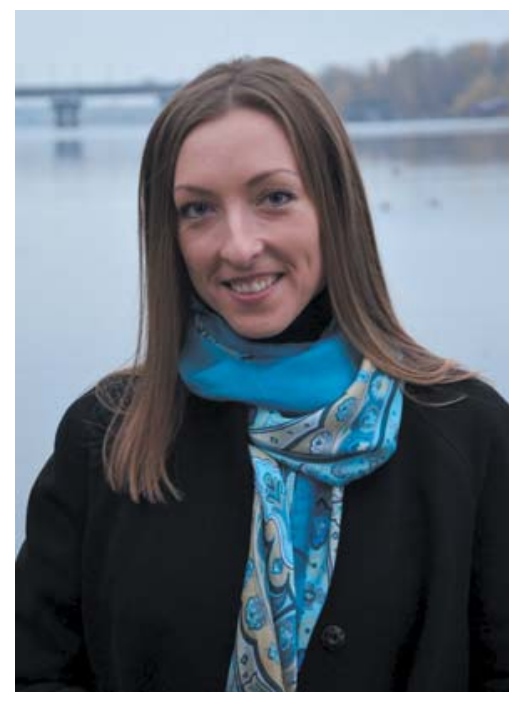

MYXA

Юлія Петрівна кандидат хімічних наук, старший науковий співробітник лабораторії фотоніки оксидних наносистем Інституту хімії поверхні ім. О.О. Чуйка НАН України

\section{ПЛАЗМОННІ МОНО-}

ТА БІМЕТАЛІЧНІ НАНОЧАСТИНКИ ЗОЛОТА І СРІБЛА ЯК ПЕРСПЕКТИВНІ ЗАСОБИ КОМПЛЕКСНОЇ ТЕРАПIÏ ОНКОЗАХВОРЮВАНЬ

\author{
За матеріалами наукового повідомлення \\ на засіданні Президії НАН України \\ 11 вересня 2019 року
}

У представленому циклі робіт розроблено і відпращвовано системний підхід до одержання стабільних наночастинок золота, срібла та іх біметалічних композицій у водному середовищі за присутності біосумісного компонента - незамінної амінокислоти триптофану. Продемонстровано, що склад нанорозмірних частинок Ag/Аи визначає як характеристики смуги локалізованого поверхневого плазмонного резонансу металу у спектрах поглинання, так і їх біологічну активність. Показано можливість спрямованого синтезу наночастинок металів з контрольованими характеристиками з використанням хімічного та фотохімічного методів. Встановлено експериментальні умови отримання магніто-плазмонних нанокомпозитів як препаратів для комплексної терапї онкозахворювань.

Ключові слова: наночастинки, золото, срібло, біметалічні, локалізований поверхневий плазмонний резонанс, триптофан, магніто-плазмонні наносистеми.

Одним з перспективних напрямів розвитку нанотехнологій є клінічна та діагностична наномедицина. Останніми роками дослідники в галузі діагностичної наномедицини особливу увагу приділяють створенню багатофункціональних нанокомплексів для молекулярного розпізнавання і візуалізації патологічних утворень на ранніх стадіях, тоді як фахівці в галузі клінічної наномедицини розробляють прототипи нанопрепаратів для цільової терапії низки захворювань, зокрема онкологічних.

Онкологічні захворювання - масштабна світова проблема. За даними Державної служби статистики України, злоякісні новоутворення (рак) є другою за кількістю випадків причиною смертності населення в Україні після серцево-судинних захворювань. Потенціал благородних металів як протиракових 
смарт-агентів для цільової доставки, молекулярної діагностики та індивідуальної терапії постійно зростає [1, 2]. Більше того, є підтвердження результатів фундаментальних досліджень у клінічній практиці, а препарати на основі нанорозмірного золота вже застосовують у методах гіпертермії та імунотерапії [3]. Тому в наведеному нижче дослідженні основну увагу було спрямовано на розроблення функціональних нанорозмірних систем на основі золота, срібла та їх біметалічних композицій для медичного застосування, зокрема для терапії онкозахворювань.

Специфічний яскравий колір є характерною ознакою наночастинок благородних металів. Він зумовлений явищем плазмонного резонансу (локалізованого поверхневого плазмонного резонансу - ЛППР), від чого походить і назва - плазмонні метали. Завдяки ЛППР у видимому діапазоні спектра спостерігається смуга поглинання, характеристики якої містять інформацію про систему. Положення та інтенсивність смуги залежать насамперед від властивостей металу, з якого утворена наночастинка, а їі максимум може зміщуватися при зміні розміру частинок. Форма смуги залежить від форми частинок та їх самоорганізації в системі. За зміною смуги ЛППР відстежують зміни у системі наночастинок металів та аналізують пов’язані з ними процеси.

Наночастинки золота і срібла одержують як у рідині, так і на поверхні різних твердих носіїв. Для застосування 3 терапевтичною метою наночастинки мають перебувати в колоїдному стані у водному середовищі. Зазвичай для синтезу наночастинок металів у колоїдному розчині використовують сильні відновники іонів металів (тетрагідроборат натрію $\mathrm{NaBH}_{4}$ ) та стабілізатори частинок у вигляді поверхнево-активних речовин (додецил сульфат натрію (ДСН), цетилтриметиламоній бромід (ЦТАБ)). Ці реагенти дають змогу отримувати стабільні системи нанорозмірних металів, однак при цьому вони можуть спричиняти токсичні ефекти. В нашій роботі ми замінили традиційні відновник іонів металу і стабілізатор частинок на біосумісний компо-
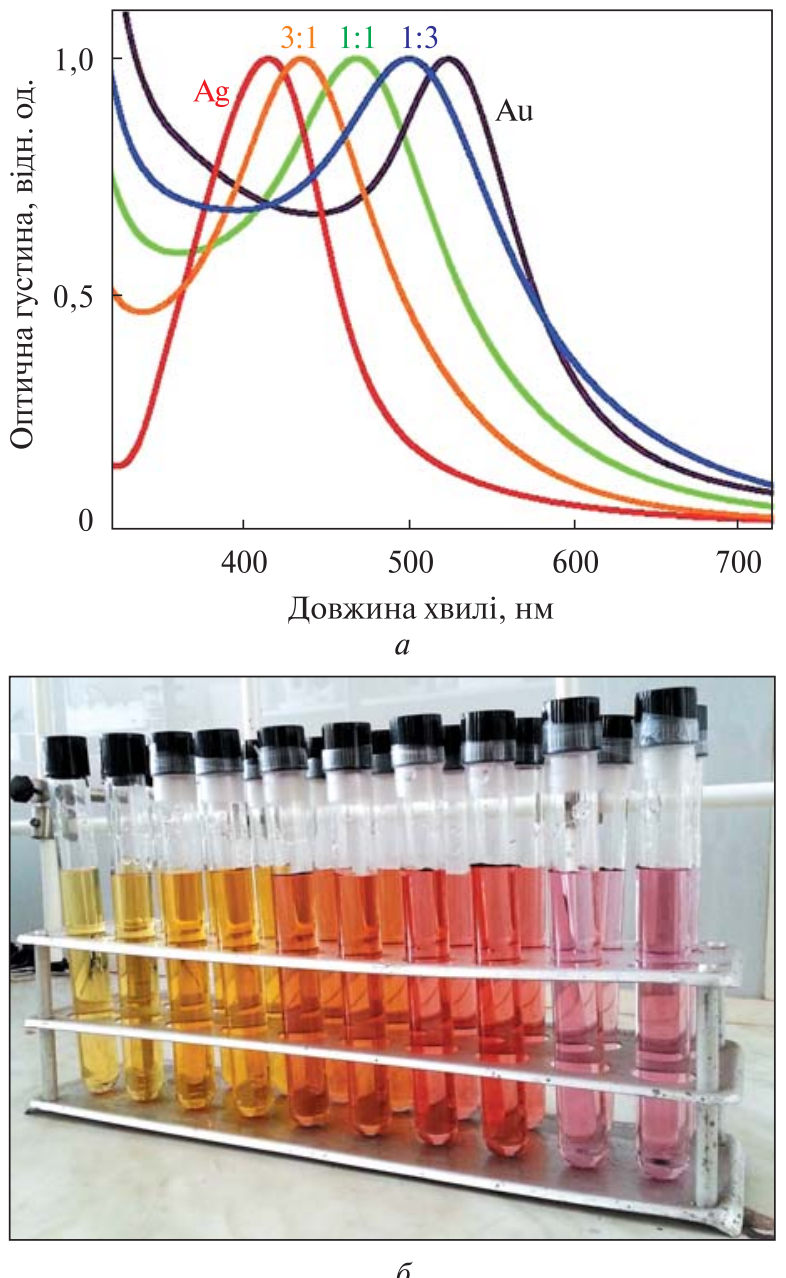

Puc. 1. Спектри поглинання колоїдних розчинів моноі біметалічних наночастинок срібла та золота $(a)$ та їх забарвлення (б)

нент - незамінну амінокислоту триптофан, яка відіграє подвійну відновну та стабілізуючу функцію. Це дозволило поліпшити ряд біологічних показників у дослідженнях in vivo на тваринах, зокрема при застосуванні біметалічної композиції срібло/золото на мишах 3 прищепленою карциномою легень Льюїса. Так, було досягнуто зменшення розміру та маси первинної пухлини, середнього розміру метастазів і підвищення рівня виживання загалом. Використання триптофану сприяло зниженню гепато- і нефротоксичного впливу нанокомпозиту [4]. 

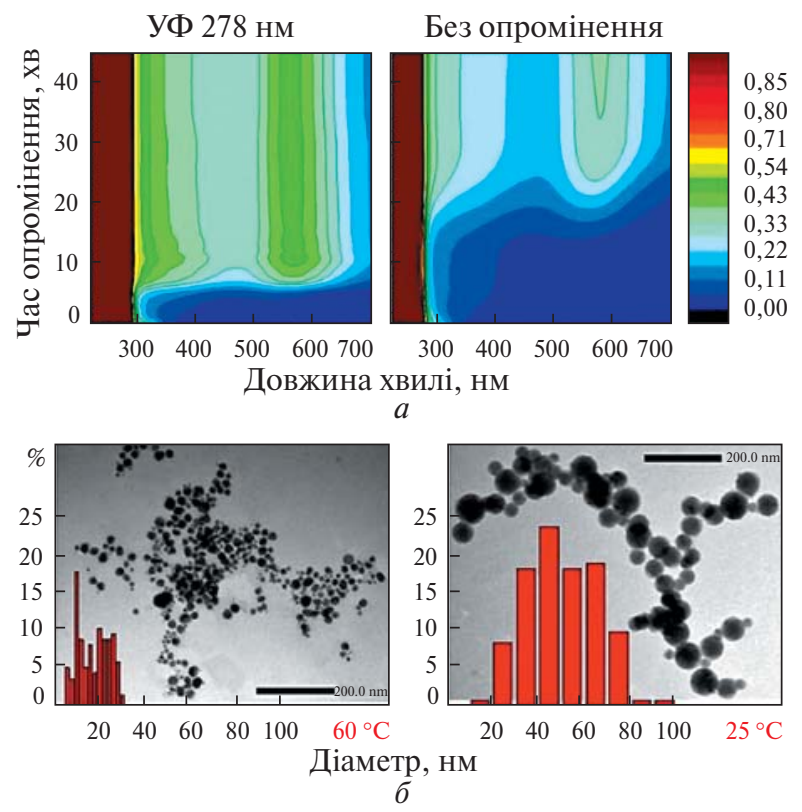

Puc. 2. Зміна інтенсивності смуги поглинання наночастинок золота в часі при опроміненні системи світлом 3 довжиною хвилі 278 нм та без опромінення $(a)$; електронно-мікроскопічне зображення та розподіл за розмірами наночастинок срібла, одержаних при опроміненні за температур 60 і $25^{\circ} \mathrm{C}$ (б)

Результати досліджень біологічного впливу наночастинок, одержаних у присутності триптофану, спонукали до вдосконалення експериментальних методик їх синтезу з метою підвищення стійкості колоїдних розчинів та визначення оптимального складу частинок для досягнення найвищої біологічної ефективності. Було розроблено методику отримання низки колоїдних систем, стабільність яких не втрачається протягом 3-5 років при зберіганні за нормальних умов.

Кислотність вихідних компонентів істотно впливає на властивості отриманих наночастинок, зокрема на поверхневий заряд і розподіл частинок за розмірами, адже амінокислота залежно від $\mathrm{pH}$ може існувати в катіонній, нейтральній або аніонній формах, а сполуки металу можуть формувати гідроксокомплекси, що, в свою чергу, впливає на перебіг окисновідновного процесу. Показано, що для одержання найбільш стабільних наночастинок 3 найвужчим розподілом за розмірами хімічне відновлення іонів металів слід проводити в лужному середовищі за температури кипіння. При цьому контроль параметрів отриманих наночастинок здійснюється за вихідними концентраціями та співвідношеннями реагентів. У досліджених системах утворюються сферичні частинки розміром до 30 нм, що підтверджено методом електронної мікроскопії. За даними адсорбційної та мас-спектрометрії визначено, що трансформація триптофану в таких системах відбувається через кінуреніновий шлях, аналогічно перетворенню амінокислоти в організмі людини. Тобто і триптофан, і продукти його окиснення є біосумісними і сприяють зменшенню токсичності нанооб'єктів [5].

Розроблену методику було використано для синтезу біметалічних наночастинок срібло/ золото як потенційно більш ефективних. Визначено оптимальні експериментальні умови для синтезу низки стабільних біметалічних наночастинок типу сплав з різним співвідношенням металів [6] і продемонстровано, що склад наночастинок $є$ фактором, який визначає насамперед оптичні властивості системи (рис. 1). Колоїдні розчини нанорозмірних металів мають характерне жовте (срібло) та червоне (золото) забарвлення. У спектрах поглинання максимуми смуг ЛППР металів розташовані у видимій ділянці спектра при 420 та 525 нм відповідно. У випадку біметалічних наночастинок срібло/золото (Ag/Au) типу сплав максимум смуги ЛППР лежить між максимумами смуг індивідуальних металів і залежить від їх вмісту в частинці. Смуга зміщується у довгохвильову ділянку від срібла до золота поступово, відповідно до зменшення молярного співвідношення металів Ag:Au у наночастинці, що супроводжується послідовною зміною кольору від жовтого до червоного.

Виявлено залежність біологічної активності наночастинок (протиракового ефекту) від вмісту золота і срібла в частинці. Зокрема, в дослідженнях in vitro на трьох лініях онкоклітин та клітинах контрольної групи продемонстровано, що серед отриманих зразків моно- i біметалічних наночастинок з різним співвідношенням золота і срібла саме біметалічні час-

ISSN 1027-3239. Visn. Nac. Acad. Nauk Ukr. 2019. (10) 

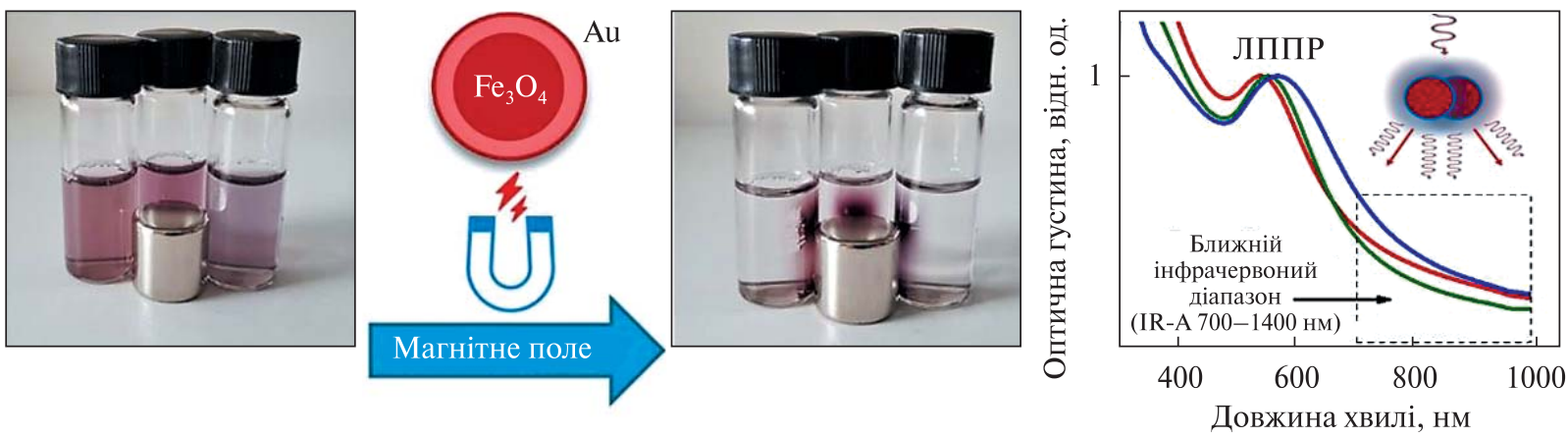

Puc. 3. Магніто-плазмонні наносистеми на основі золота та магнетиту і їх спектри поглинання

тинки Ag/Au зі співвідношенням металів 3:1 виявляють максимальний протираковий ефект і можуть слугувати перспективною основою для розроблення прототипів протипухлинних нанопрепаратів [7, 8].

У роботі було використано також інший підхід до одержання біметалічних частинок метод послідовного відновлення іонів металів для приготування наночастинок типу ядрооболонка. Такі наночастинки характеризуються наявністю однієї смуги ЛППР у спектрах поглинання, положення якої залежить від розподілу металів у межах частинки. При формуванні наночастинок типу ядро-оболонка спостерігається різка зміна забарвлення колоїдних розчинів. Про утворення оболонки нового металу на поверхні іншого свідчить виникнення нової смуги поглинання ЛППР після зникнення смуги поглинання попередньо сформованого «ядра». Такий процес відбувається в обох системах $\mathrm{Ag}_{\text {ядро }} / \mathrm{Au}_{\text {оболонка }}$ та $A \mathrm{u}_{\text {ядро }} / \mathrm{Ag}_{\text {оболонка }}$. Показано, що склад і будова наночастинок є факторами, що визначають їх протипухлинну активність. Виявлено, що в умовах експерименту in vivo на мишах з прищепленою карциномою легень Льюїса найефективнішими є біметалічні наночастинки типу $\mathrm{Ag}_{\text {ядро }} / \mathrm{Au}_{\text {оболонка' }}$ які можуть стати основою функціональних протипухлинних наноматеріалів [9].

Оскільки триптофан $є$ фотоактивною молекулою і має смугу у спектрі поглинання з максимумом в ультрафіолетовому діапазоні при 280 нм, запропоновано метод фотохімічного відновлення іонів металу в присутнос- ті триптофану з використанням опромінення ультрафіолетового діапазону, яке активує окисно-відновний процес за нижчих температур і дозволяє системно змінювати та контролювати цільові характеристики одержуваних наночастинок залежно від параметрів опромінення системи, таких як потужність та тривалість опромінення, температури реакції та ін. (рис. 2) [10, 11].

Ще один ефект, який використовують у медицині з діагностичною метою, - це зміна забарвлення системи при взаємодії частинок між собою. Асоціація (агрегація) наночастинок золота, для яких характерне явище ЛППР, може спричиняти суперпозицію та підсилення електричних полів у точках їх взаємодії i, як наслідок, зсув максимуму поглинання системи в довгохвильову ділянку спектра. Зміщення смуги ЛППР у «червону ділянку» було продемонстровано на прикладі наночастинок золота, отриманих з використанням цитрату натрію, під час взаємодії з тіолвмісними сполуками, які слугували агентами зв'язування наночастинок [12].

Подібне зміщення поглинання системи в ближню інфрачервону ділянку дає змогу використовувати в подальшому з терапевтичною метою саме ІЧ-світло, зокрема в методі гіпертермії для розігріву наносистеми (фототермічний ефект). А поєднання оптичних властивостей металу і магнітних властивостей оксиду заліза дозволить створити магнітокеровані плазмонні наносистеми, адаптовані до ближнього інфрачервоного діапазону. 
Для синтезу магніто-плазмонних нанооб’єктів на основі благородних металів та триптофану використовували як хімічний $[13,14]$, так і фотохімічний методи з опроміненням ультрафіолетового діапазону. Розроблена методика дає можливість отримувати нанорозмірні системи, які зберігають оптичні властивості нанорозмірного металу та реагують на магніт, при цьому вся система проявляє поглинання в діапазоні довгих хвиль (рис. 3).

Отже, в результаті проведених досліджень розроблено та відпрацьовано експериментальні методики, які відкривають шляхи для створення функціонального нанопрепарату спрямованої дії на основі наночастинок срібла і золота для комплексної терапії онкозахворювань. Використання біосумісного відновника/стабілізатора - незамінної амінокислоти триптофану сприятиме зниженню токсичних ефектів наносистеми, тоді як ядро оксиду заліза уможливить спрямовану доставку препара- ту у визначену ділянку тіла за допомогою магнітного поля, а використання інфрачервоного опромінення 3 високою проникністю крізь шкіру дозволить зменшити побічні ефекти від хіміо- і радіотерапії.

Роботу виконано в рамках програм Інституту хімї поверхні ім. О.О. Чуйка НАН України та за підтримки грантів НАН України молодим ученим НАН Украӥни на реалізаџію проекту НДР 2015-2016 «Фоточутливі композити з пікосекундним оптичним відгуком на основі похідних діарилетенів $i$ наночастинок срібла та золота» та молодіжним лабораторіям $i$ дослідницьким лабораторіям/групам молодих вчених НАН України для проведення досліджень за пріоритетними напрямами розвитку науки i техніки у 2018-2019 рр. «Розробка магнітноплазмонних наноматеріалів з акустичним відгуком як засобів фототермальної терапії та мультимодальної діагностики».

\section{REFERENCES}

\section{[СПИСОК ЛІТЕРАТУРИ]}

1. Sztandera K., Gorzkiewicz M., Klajnert-Maculewicz B. Gold Nanoparticles in Cancer Treatment. Mol. Pharm. 2019. 16(1): 1. DOI: https://doi.org/10.1021/acs.molpharmaceut.8b00810

2. Grumezescu A.M. (ed.) Nanobiomaterials in Cancer Therapy. Applications of nanobiomaterials. Vol. 7. Elsevier, 2016. DOI: https://doi.org/10.1016/C2015-0-00383-5

3. Shi J., Kantoff P.W., Wooster R., Farokhzad O.C. Cancer nanomedicine: progress, challenges and opportunities. Nat. Rev. Cancer. 2017. 17(1): 20. DOI: https://doi.org/10.1038/nrc.2016.108

4. Shmarakov I.O., Mukha Iu.P., Karavan V.V., Chunikhin O.Yu., Marchenko M.M., Smirnova N.P., Eremenko A.M. Tryptophan assisted synthesis reduces bimetallic gold/silver nanoparticle cytotoxicity and improves biological activity. Nanobiomedicine. 2014. 1: 1. DOI: https://doi.org/10.5772/59684

5. Mukha Iu., Vityuk N., Severynovska O., Eremenko A., Smirnova N. The pH-dependent structure and properties of $\mathrm{Au}$ and Ag nanoparticles produced by tryptophan reduction. Nanoscale Res. Let. 2016. 11: 101. DOI: https://doi. org/10.1186/s11671-016-1318-8

6. Vityuk N., Mukha Iu., Grodzyuk G., Eremenko A. Bimetallic gold/silver alloy nanoparticles prepared in the presence of tryptophan. Poverkhnia (Surface). 2016. 8: 118.

7. Mukha Iu., Vityuk N., Grodzyuk G., Shcherbakov S., Lyberopoulou A., Efstathopoulos E.P., Gazouli M. Anticancer effect of Ag, Au, and Ag/Au bimetallic nanoparticles prepared in the presence of tryptophan.J. Nanosci. Nanotechnol. 2017. 17(12): 8987. DOI: https://doi.org/10.1166/jnn.2017.14106

8. Katifelis H., Lyberopoulou A., Mukha Iu., Vityuk N., Grodzyuk G., Theodoropoulos G.E., Efstathopoulos E.P., Gazouli M. Ag/Au bimetallic nanoparticles induce apoptosis in human cancer cell lines via P53, CASPASE-3 and BAX/ BCL-2 pathways. Artificial Cells, Nanomed. Biotechnol. 2018. 46(sup3): 389. DOI: https://doi.org/10.1080/2169140 1.2018.1495645

9. Shmarakov I., Mukha Iu., Vityuk N., Borschovetska V., Zhyshchynska N., Grodzyuk G., Eremenko A. Antitumor Activity of Alloy and Core-Shell-Type Bimetallic AgAu Nanoparticles. Nanoscale Res. Let. 2017. 12(1): 333. DOI: https:// doi.org/10.1186/s11671-017-2112-y 
10. Mukha Iu., Vityuk N., Khodko A., Kachalova N., Fedyshyn O., Malysheva M., Eremenko A. Photo- and temperaturedependent formation of tryptophan/silver nanoparticles. Res. Chem. Interm. 2019. 45(8): 4053. DOI: https://doi. org/10.1007/s11164-019-03890-5

11. Mukha I., Khodko A., Vityuk N., Severynovska O., Pivovarenko V., Kachalova N., Smirnova N., Eremenko A. Lightdriven formation of gold/tryptophan nanoparticles. Appl. Nanosci. 2019. DOI: https://doi.org/10.1007/s13204-01901171-6

12. Khodko A., Kachalova N., Scherbakov S., Eremenko A., Mukha Iu. Effects of photochromic furan-based diarylethenes on gold nanoparticles aggregation. Nanoscale Res. Let. 2017. 12(1): 271. DOI: https://doi.org/10.1186/s11671-0172044-6

13. Pylypchuk Ie.V., Mukha Iu.P., Vityuk N.V., Szczepanowicz K., Storozhuk L.P., Eremenko A.M., Warszyński P., Gorbyk P.P. Tryptophan-Stabilized Plasmonic $\mathrm{Fe}_{3} \mathrm{O}_{4} / \mathrm{Ag}$ Nanoparticles. In: Fesenko O., Yatsenko L. (eds) Nanophotonics, Nanooptics, Nanobiotechnology, and Their Applications. Proc. NANO 2018. Vol. 222. Springer Cham., 2019. P. 417-430. DOI: https://doi.org/10.1007/978-3-030-17755-3_28

14. Lyberopoulou A., Grammaticaki St., Mukha Iu., Vityuk N., Pylypchuk Ie., Storozhuk L., Kouloulias V., Gazouli M. In vitro effect of hyperthermic $\mathrm{Ag}$ and $\mathrm{Au} \mathrm{Fe}_{3} \mathrm{O}_{4}$ nanoparticles in cancer cell cultures. Beilstein Arch. 2019, 2019101 (One-Day-Symposium on Nanotechnology in Health Science, 21 January, 2018, Athens, Greece). DOI: https://doi. org/10.3762/bxiv.2019.101.v1

\section{Iu.P. Mukha}

Chuiko Institute of Surface Chemistry of the National Academy of Sciences of Ukraine (Kyiv)

PLASMONIC MONO- AND BIMETALLIC NANOPARTICLES OF GOLD AND SILVER AS PROMISING TOOLS OF COMPLEX THERAPY OF CANCER

According to the materials of scientific report at the meeting of the Presidium of NAS of Ukraine, September 11, 2019

In the presented work, a systematic approach is developed to prepare stable colloids of noble metal nanoparticles (NPs) as promising agents for cancer treatment. Mono- and bimetallic gold and silver NPs of alloy and core-shell type were prepared in aqueous medium using biocompatible component tryptophan as metal reducer and particle stabilizer.

The impact of metal components/composition as well as metal topological distribution within NPs on optical properties and biological activity is discussed. Only one localized surface plasmon resonance (LSPR) band is characteristic for bimetallic NPs. In case of alloy $\mathrm{Ag} / \mathrm{Au}$ nanoparticles the maximum is located between the maxima inherent to the LSPR bands of individual metals and shifts from $411 \mathrm{~nm}$ (silver) to $526 \mathrm{~nm}$ (gold) with decreasing Ag:Au molar ratio. In case of bimetallic core-shell NPs LSPR absorption band of previously formed monometallic particles, used as a core, disappears during the synthesis while LSPR band of the second metal grows in the spectra of the same colloid. Among studied alloy systems Ag/Au nanoparticles with metal ratio 3:1 had the maximal anticancer effect towards HCT116, 4T1, HUH7 cell lines, while the toxicity was found significantly decreased in non-cancerous HEK293 cell lines. During antitumor activity studies in vivo on mouse with Lewis lung carcinoma treated with alloy ( $\mathrm{Ag}: \mathrm{Au}=3: 1,1: 1,1: 3)$ and core-shell nanoparticles. $\left(\mathrm{Au}_{\text {core }} / \mathrm{Ag}_{\text {shell }}, \mathrm{Ag}_{\text {core }} / \mathrm{Au}_{\text {shell }}\right.$ ), the system with $\mathrm{Ag}$ core covered by $\mathrm{Au}$ shell appeared to be the most effective.

The synthesis of nanoparticles with controlled properties was demonstrated with the use of chemical and photochemical methods. The activation of redox process between metal ions and tryptophan with UV irradiation at $280 \mathrm{~nm}$, corresponding to the position of the indole absorption band of amino acid, allows to affect the optical properties of the system, characteristics of nanoparticles and their self-assembling in colloid depending on experimental parameters like temperature of reaction, output optical power density and duration of irradiation.

Chemical and photochemical methods were applied for preparation of magneto-plasmonic nanostructures composed of magnetic iron oxide core and gold/silver shell. The optical properties of magneto-plasmonicFe $\mathrm{O}_{4} / \mathrm{Au}(\mathrm{Ag})$ nanocomposites, namely position of plasmon resonance band maximum and absorbance in near infrared region, can be adjusted by varying the temperature of reaction from 25 to $100^{\circ} \mathrm{C}$ and applying UV irradiation. Such nanosystems possess properties inherent to both individual components and can be applied in biomedical field for targeted drug delivery and therapy.

Keywords: nanoparticles, gold, silver, bimetallic, localized surface plasmon resonance, tryptophan, magneto-plasmonicnanosystems. 